\title{
Gifted Education in the Republic of Tatarstan: New Challenges and Innovative Decisions
}

\author{
Nadezhda P. Pomortseva ${ }^{1} \&$ Elena V. Gabdrakhmanova ${ }^{1}$ \\ ${ }^{1}$ Kazan (Volga Region) Federal University, Kazan, Russia \\ Correspondence: Nadezhda P. Pomortseva, Kazan (Volga Region) Federal University, 420008, Kazan, \\ Kremlyovskaya Street, 18, Russia. E-mail: nadpom@rambler.ru
}

Received: June 2, 2015 Accepted: June 15, 2015 Online Published: June 29, 2015

doi:10.5539/jsd.v8n5p218

URL: http://dx.doi.org/10.5539/jsd.v8n5p218

\begin{abstract}
The issues discussed in the paper are urgent as the Republic of Tatarstan (the RT), situated in the Volga Region of the Russian Federation, places a great emphasis on the correct identification and education of its gifted and talented (G/T) children and youth. Having achieved a considerable success in the field the RT, however, still faces a number of challenges for successful implementation of the decisions made on municipal, republican and federal levels. The aim of the research is to collect and analyze the main issues to tackle and challenges to meet in order to improve the work with G/T learners in the Republic of Tatarstan and about. The leading approach used by the authors was the descriptive method for observation and classification of the investigated material as well as interviewing, collecting, analyzing and synthesizing the data, received via interviews and questionnaire to summarize the general state of the G/T education in the Republic of Tatarstan. Thus the authors managed to define the main problems in the organization and implementation of work with gifted children in educational institutions of the Republic of Tatarstan; to interpret the results of a monitoring research on the quality of services in the field of education and to outline the possible fast track for boosting the system of identification and teaching the G/T students in the Republic of Tatarstan. The paper might be of interest for municipal, republican and national, public and independent institutions and organizations and individuals involved in nurturing the unique abilities and needs of a most valuable human resource of a country - the gifted and talented children and youth.
\end{abstract}

Keywords: the gifted and talented (G/T) children and youth, school and further educational institutions, the Republic of Tatarstan (the RT)

\section{Introduction}

\subsection{Background}

Gifted and talented $(\mathrm{G} / \mathrm{T})$ child is a child/youth who demonstrates bright, obvious, sometimes outstanding achievements (or has internal prerequisites for such developments) in one or another activity. Today, most psychologists and educators recognize that the level, quality and originality of the character of genius is always the result of a complex interaction of heredity (natural abilities and aptitudes) and the social environment, mediated by the activity of the child (playing, training, employment) (Gagne, 1994).

Conventionally, there are three categories of gifted children:

- Children with unusually high general level of mental development, ceteris paribus. These children are most often found in the preschool and early school age (Shumakova, 2012);

- Children with signs of a exceptional intelligence in a certain field of science - usually characteristic of teenagers (Terman, 1959 as cited in Pomortseva, 2014).

- Underachievers, however, demonstrating bright cognitive activities, original mentality, extraordinary mental reserves - more common for high-school age (Heller, 1991).

Modern trends of social development put new challenges before education marked by an increased interest in the gifted and talented children: away from focusing on the "average" student to the peculiarities of recognizing and developing their skills in the process and by means of education (Renzulli, 1998).

In the Russian Federation, one of the priorities of the state policy in the field of education is the 
socio-educational support and development of $\mathrm{G} / \mathrm{T}$ children and youth as a priceless national heritage and principal intellectual and creative potential of the country.

The Act On Education in the Russian Federation guarantees assistance to persons, who have shown outstanding ability. These include students, who showed a high level of intelligence and creative skills in a particular area of training and research activities, in the scientific, technical, artistic fields and sports (On Education, 2012).

Practice shows that the main role in the identification and organization of work with gifted children is played by educational institutions of school and further education (Zhigaylov, 2001). They actively involve learners into Student Academic Olympics, contests and other competitive activities that often distinguish students who have already demonstrated high performance in a particular academic discipline, arts or sport. Much of the talented and gifted children remain undiagnosed or misdiagnosed because the methods used in most cases do not reveal a hidden talent (Osborn, 2014). But it's only a part of the main problem. These forms, however, do not allow to discover children's abilities and aptitudes which have not yet manifested themselves in academic achievements (Renzulli \& Richards, 2000). Moreover, the educational environment in the educational institutions where they learn may not be focused on their support. One of the reasons for misdiagnosis of a particular type of giftedness may be lack of necessary knowledge and skills, as well as limited or no access to the domain of activity, corresponding to the child's talent, due to the socio-economic conditions of living (Savenkov, 2002).

Thus many G/T/ learners may miss an opportunity to be nominated for gifted enrichment programs where they are offered creativity workshops, contests, research conferences; student academic Olympics; arranged in cluster grouping and offered individual plan; do electives, out-of class and out-of school individual and group projects, including those with institutions of further education for $\mathrm{G} / \mathrm{T}$ children and youth, with the universities and research and art centers for G/T children of the country; get to know people of similar abilities and aptitudes (Bogoyavlenskaya, 2002; Pomortseva, 2014).

The further development of even recognized G/T child/youth is often hindered by lack of proper communication with potential investors or interested government officials, impossibility to be published in an established journal or Internet site or presented at the conference, limited access to a good recording studio or up-to-date equipment (The concept, 2012).

As a result, $\mathrm{G} / \mathrm{T}$ educators reduce themselves to working with those children whose giftedness is obvious, who, thanks to their ability, or the enabling environment, basically the family, were able to show themselves to advantage. Meanwhile, truly systematic work in promoting national talents means catering for the widest possible manifestations of talents and nurturing them (Rubtsov \& Margolis, 2009).

\subsection{Status of a Problem}

A gifted child in the process of development goes beyond the school ccurriculum, selects the services provided by other types of educational institutions of technology, art and sports. Much of the fate of these children will depend on the specific characteristics of training and education. Here we shall have to go not only about building an individual learning route based on a student-centered approach, but about creating the conditions for an student-tailored, differentiated instruction, which must be carried out by the professionals, well versed in the specifics of educating G/T children (Bogoyavlenskaya, 2002).

The basic principles to provide for the effectiveness of work with gifted children in the regular school (such as the individualization of the learning route, ensuring the proper competence of teachers and psychologists enabling them to work with different groups of children, assessment of educational institutions with regards to serving various categories of children etc.) must be formulated as a basis of the educational system, i.e., at the level of state educational standards. (Rubtsov \& Margolis, 2009).

The main problem of educating gifted children, determined at the government level is lack of consistency challenged by magnitude of this work (The Concept, 2012).

The concept of long-term socio-economic development of the Russian Federation for the period up to 2020 sets the task of developing a system of identification and support of G/T children and youth as a way of modernization of the education institutions in general (Order, 2008).

Facing these problems puts forward the need to create an innovative educational environment based on education, art, sports, youth affairs interagency cooperation, which will create new conditions and means of promoting the development of gifted and talented children in the Republic of Tatarstan. 


\section{Methodological Framework}

\subsection{Thematic Justification}

We find the problem, raised in the paper, crucial because G/T children and youth, if properly diagnosed and nurtured, can considerably contribute to the social-economic and cultural growth of the country. Obvious lack of researches in the field of developing and implementing the goals of G/T education in the Republic of Tatarstan leaves teachers, parents and $\mathrm{G} / \mathrm{T}$ students themselves in the informational and psychological desert. The ill-informed and unprepared environment often fails to meet the challenge of G/T children' unique abilities and needs, and tend to regard them as a burden which otherwise could be used to advantage.

\subsection{Objectives of the Research}

In order to implement The Gifted Children Sub-Plan №4 of the long-term target program The Children of Tatarstan for 2011 - 2013 implemented by the Ministry of Education and Science of the Republic of Tatarstan the monitoring of work with gifted children of the Republic of Tatarstan becomes especially important. The survey made will allow to upgrade the $\mathrm{G} / \mathrm{T}$ identification and education technologies correspondingly and determine the role of educational institutions of further education in the development, support and maintenance of $\mathrm{G} / \mathrm{T}$ children.

The following issues objected in the research are presented in the paper:

1) summarizing the general state of the GT education in the Republic of Tatarstan;

2) defining the problems in the organization and implementation of work with gifted children in educational institutions of the Republic of Tatarstan;

3 ) interpreting the results of a monitoring research on the quality of educational services in the field of education;.

4) outlining the possible fast track for boosting the system of identification and teaching the GT students in the Republic of Tatarstan.

\subsection{Methods of the Research}

The following theoretical methods were used to achieve a goal and the solution of the research problems:

- descriptive method for observation and classification of the investigated material the system oriented analysis of psychological and pedagogical research and practice literature on the problem;

- generalization of innovative pedagogical experience in identification and education of GT students;

- interviewing, collecting, analyzing and synthesizing data.

Theoretical and methodological basis of the research were primarily works of domestic researchers, gifted educators and teachers as Yu. D. Babayeva (1997) as cited in D. V. Bogoyavlenskaya (2002), A. M. Matyushkin (1999), A. I. Savenkov (2002), G. D. Kuznetsova \& K. N. Shadrov (2010), N. B. Shumakova (2012), who have been engaged in the study of problems of $\mathrm{G} / \mathrm{T}$ education in the Russian Federation. The study also includes the analysis of works of international authors on the theory and practice of identification and teaching G/T children, such as L.M. Terman (1959), K. A. Heller (1991), F. Gagne (1994), J. S. Renzulli (1998), L.K. Silverman (2013), J. B. Osborn (2014).

\subsection{Factual Material of the Research}

The current research interpreted the opinions of 104 female school and further education teachers, who joined the in-service training course on Working with G/T Children/Youth in Kazan, the capital of the Republic of Tatarstan, Russian Federation. The average age was 46.7 years ranging from 32 to 60 years old. The participants varied greatly in terms of the length of their teaching experience. The mean years of teaching practice was 22.55 with a standard deviation 3.08 from the mean.

The respondents were offered to answer a few questions on the Challenges on the G/T Education in the Republic of Tatarstan which were later reviewed and arranged in the survey. The choice of the respondent group and the research material is explained by the necessity to analyze the opinions of those who deal with (potentially) G/T students in their everyday practice and, in comparison with most family members, for example, are able to express objective professional opinion.

The instrument used in this study was the interview and the questionnaire, "the most common method of collecting survey data" (De Vavs, 2001). The data were analyzed via counting the amount of answers that go under a 
particular category. The figures presented in the paper were the percentage of those who supported this or that point of view (out of $100 \%$ ).

\section{Results}

During the preliminary session the respondents noted the favorable research and communication environment for teachers and G/T children the Republic of Tatarstan. It was found that in the majority of municipal districts of the Republic of Tatarstan there has been developed a program of work with gifted children. Mentors of the G/T students actively network with teachers, educators in general education and gifted enrichment programs.

However, it should be noted that teaching G/T children in the schools of the Republic does not cater for the individual learning route.

Excluding the information irrelevant for this paper the authors can exemplify their arguments with the following quantitate information:

$75 \%$ of respondents indicated equipment and methodological base for gifted education as completely sufficient, $10 \%$ - as partly sufficient.

$65 \%$ of respondents report that in their educational institution or district the general program of G/T education has been launched.

$5 \%$ of educational institutions of the RT maintain their own system of tracking the G/T students. This fact considerably complicates the process of tracking and identification of $\mathrm{G} / \mathrm{T}$ children making it time and staff-consuming.

Only a small part of educational institutions of the Republic of Tatarstan apply a variety of innovative methods and technologies to identify creative, artistic and intellectual talents of students.

As a result of the identification procedure in the municipals the information is collected to contribute to the RT Data Bank on the GT Children. Such a scheme is applied in only as few municipal education authorities (as noted $27 \%$ of respondents). In others a guidance center is being developed.

This is largely due to lack of adequate staff commitment. The study showed that gifted education is to a greater extent carried out by devout teachers of various academic subjects and teachers of further education rather than specially trained gifted specialists. Obviously, more intensive collaboration of interested university and college staff and researchers is required to boost the recognition and provision of the unique academic needs of the $G / T$ students.

Respondents expressed a wish to provide methodological guidance for the organization of work with G/T children and youth. This includes:

- manuals on innovative but affordable, real-life methods and techniques of identification and education of G/T children including those of various aspects of giftedness;

- distance training on identification and education of G/T children, from primary school age and on.

- a properly trained school psychologist to maintain innovative $\mathrm{G} / \mathrm{T}$ identification and education methods children on site;

- regular research conferences, work-shops (including those of distance type with university professors) on Gifted Education;

- workshops for teachers to prepare for the Academic Olympics;

- meetings, workshops, 'round tables' (including those of distance type) with researchers from different areas of science to boost G/T teachers' advanced knowledge and skills in the subjects they give;

- continuous maintenance and availability of the RT Data Bank on the GT Children;

- organization and continuous upgrade of special sites and portals for G/T children and their teachers;

- assistance in organization of cooperation with universities, research institutions, including that of distance $\mathrm{G} / \mathrm{T}$ mentorship and education;

It follows that $\mathrm{G} / \mathrm{T}$ education in the Republic of Tatarstan, along with achievements, also faces a number of challenges, among which the most evident is the lack of inter-agency cooperation in nurturing the G/T students, including:

- inadequate network between various governmental and independent agencies as well as different educational institutions dealing with identification and education of $\mathrm{G} / \mathrm{T}$ children; 
- limited communication in the framework of region - municipality - educational institution providing continuous social and educational support of G/T children/youth in the society and the country;

- unreliable system of providing technological guidance to school teachers and further education specialists involved in the organization of work with G/T children;

- no system of training teaching and managerial staff of various departments of governmental and independent institutions responsible for the provision for the GT students;

- lack of cooperation with G/T students' families in terms of support and maintenance of their children' giftedness;

- challenged system of diagnostic procedures and techniques aimed at identifying gifted children; there is no continuous monitoring of their ongoing advancement in society in the region;

- lack of the established RT Data Bank on the GT Children.

\section{Discussions}

The Ministry of Youth Affairs, Sports and Tourism of the Republic of Tatarstan, the Ministry of Education and Science of the Republic of Tatarstan and the Ministry of Culture of the Republic of Tatarstan implement a set of measures to create conditions for the identification and support of G/T children and their creative development, advanced training of specialists working with gifted children.

This can be exemplified by a number of target programs. The first to mention is the Strategy of the Development of Education in the Republic of Tatarstan for 2010-2015, approved by the Cabinet of Ministers of the Republic of Tatarstan on December 30, 2010. Another worth mentioning is launching the E-Attendance System in the further education centers and institutions for children and youth. In 2012 there was launched a new integrated project, called School after School (should not mix it with 'detention'). Later a national educational initiative Our New School was introduced to determine the key characteristics of the modern Russian education, that is the formation of competencies.

In this context the Republic of Tatarstan can boast art, music, sports schools, secondary schools with in-depth study of particular subjects, gymnasiums (those providing for the in-depth education in arts) and lyceums (those catering for the advance placement of students to colleges of higher education). Both might even maintain special centers for $\mathrm{G} / \mathrm{T}$ children. On the basis of these organizations diagnostics, selection, training of gifted children is provided.

School institutions provide children with the opportunity to develop their abilities in groups, circles and associations specialized in arts, crafts and sports. Tatarstan today operates 160 out-of-school institutions of further education for children.

For many years, there have been thriving specialized summer schools for gifted students provided by the interested institutes of Federal University and local research centers: The Kwan, The Linguistic Leader, The Orbital, The Intelligence, The Baitik, The Selet.

The most capable and gifted children of Tatarstan annually participate in regional, national and international academic Olympics, contests, festivals, competitions.

The municipal Republican Academic Olympics Center of further education for G/T children and youth, established in the Republic of Tatarstan in 2014 as a part of the network of organizations to identify and support gifted children, is thriving. The Republican Academic Olympics Center functions under the Ministry of Education and Science of the Republic of Tatarstan, and works closely with universities, that provide for scientific guidance of the project.

The main function of the Republican Academic Olympics Center is to organize, monitor and coordinate the implementation of government policy on G/T education in the Republic; the policy which has been actively carried out in 43 municipalities of the six economic zones of the Republic of Tatarstan. Naturally, the cater for the so-called "school giftedness", that is children who show considerable advancement in the school curriculum (Renzulli \& Richards, 2000).

In these terms the 2014 statistics for the Republic of Tatarstan is breathtaking.

- The total number of participants in Academic Olympic movement in the Republic of Tatarstan is 145685 schoolchildren (including those at the school stage). 
- 2,325 students competed in 34 subjects in the final stages of national and regional stages of the All-Russian Academic Olympics. Of these, 563 participants were the winners of the regional stage of the All-Russian Academic Olympics.

- In 2014 of a few contestants taking part in international Academic Olympics by the Republic of Tatarstan, one was a gold medal winner, 2 students took a second prize.

- 73 schoolchildren of the Republic of Tatarstan became the winners of the All-Russian Academic Olympics. But it is 2 people less than in 2011 and 3 people less than in 2013.

\section{Conclusions}

In the Republic of Tatarstan, as well as in the Russian Federation as a whole, the process of forming a unified system of G/T education, purposefully and actively efforts to create conditions conducive to the development of children.

The main aim of education of G/T children in the Republic of Tatarstan today is to develop mechanisms of interaction between actors involved in gifted education in the Republic.

Therefore, the prospect of gifted education in the Republic of Tatarstan can be viewed in the following way:

- Introducing a mechanism of coordinated and efficient interagency cooperation of research, educational institutions, art, sports and other interested parties to provide for the quality identification and education of G/T children in the Republic of Tatarstan.

- Improvement of the monitoring system of provision of $\mathrm{G} / \mathrm{T}$ services in the RT in terms of nomination, identification, development and support of gifted children, working out the mechanisms for assessing the effectiveness of gifted enrichment programs, monitoring the work with $\mathrm{G} / \mathrm{T}$ children in terms of cooperation between institutions of various governmental departments of the RT.

- Attracting young talents to the implementation of innovative educational, art, technical, research and development projects and programs implemented in the Republic of Tatarstan and the Russian Federation;

- Opening the national (municipal) innovative cites to simulate nomination and correct diagnostics of G/T students as well as technology of social and pedagogical guidance of gifted children;

- Introduction of a network of Resource Centers for G/T children and their parents to support the activities of educational institutions, art, sports institutions in the Republic of Tatarstan;

- Maintenance of the RT Data Bank, the Internet portal on and for the GT children of preschool and school-age of the Republic of Tatarstan;

- Improving the regulatory legal framework for the support of G/T children in the country;

- Establishment of a comprehensive interdepartmental system of training and retraining of staff, engaged in the work with gifted children, taking into account the real needs of society, combining the trends in the development of the Russian culture, sports, education with global experience in the field.

\section{Acknowledgments}

The work is performed according to the Russian Government Program of Competitive Growth of Kazan Federal University.

\section{References}

Bogoyavlenskaya, D. B. (Ed.). (2002). Working concept of giftedness: its goals and objectives. In Giftedness: draft concept. Moscow: Executive Directorate of the Presidential Program "The Children of Russia", 12-19.

De Vavs, D. (2001). Research Design in Social Research. London: Sage Publishing.

Gagne, F. (1994). Are teachers really poor talent detectors? Gifted Child Quarterly, 38, $124-126$. http://dx.doi.org/10.1177/001698629403800305

Heller, K. A. (1991). The nature and development of giftedness: a longitudinal study. European journal for high ability, 2(2), 174-189. http://dx.doi.org/10.1080/0937445910020207

Kuznetsova, G. D., \& Shadrov, K. N. (2010). Technology of working with talented youth: a lecture course. Moscow: SMSUH. Retrieved from http://www.fkcmp.ru/docs/kurs_talant.do

Matyushkin, A. M. (1999). Giftedness and creativity: the concept, results and prospects. Jubilee scientific session devoted to the 85th anniversary of the Psychological Institute of RAO. Moscow: RAO. 
On Education in the Russian Federation. (2010). The Federal Law of the Russian Federation of December 29, 2012 № 273-FZ. Retrieved from http://www.zakonrf.info/zakon-ob-obrazovanii-v-rf/

Order by the government of the Russian Federation by November 17, 2008 №1662-r. (2008). On the Concept of long-term socio-economic development of the Russian Federation for the period till 2020 (amended). Retrieved from http://www.consultant.ru/document/cons_doc_LAW_90601/

Osborn, J. B. (2014). Gifted children: are their gifts being identified, encouraged, or ignored? Retrieved from http://www.aboutourkids.org/articles

Pomortseva, N. P. (2014). Teaching gifted children in regular classroom in the USA. Procedia - Social and Behavioral Sciences, 143, 147-151. http://dx.doi.org/10.1016/j.sbspro.2014.07.377

Renzuilli, J. S. (1998). The three ring conception of giftedness. In S.M. Reis, L.R. Mansfield (Eds). Nurturing the gifts and talents of primary grade students. Mansfield Center. CT: Creative Learning Press.

Renzulli, J. S., \& Richards, S. (2000). Gifted in the middle: addressing the needs of gifted middle schools students. Principal, 79(4). Retrieved from http://www.hoagiesgifted.org/middleschools.html

Rubtsov, V. V., \& Margolis, D. V. (2009). Gifted Education - state the problem. Psychological Science and Education, 4, 5-14.

Savenkov, A. I. (2002). The development of children's talents in the educational environment. Personal development, 3, 113-146.

Shumakova, N. B. (2012). Psychological peculiarities of development of intellectually gifted children at elementary school age. Psychological Science and Education psyedu.ru, 4. Retrieved from http://psyjournalsru/en/psyedu_ej/2012/n4/59333.shtml

The concept of a national system to identify and support young talent. (2012). Retrieved from http://kremlin.ru/events/president/news/14907

The national educational initiative "Our New School" (approved by. The President of the Russian Federation dated February 4, 2010 N 271-Pr). (2010). Retrieved from http://kremlin.ru/events/president/news/6683

The strategy of the development of education in the Republic of Tatarstan for 2010-2015. (2010). Retrieved from http://mon.tatarstan.ru/rus/kilechek.htm

Zhigaylov, A. V. (2001). Organizational-pedagogical bases of work with gifted children in a regional system of further education (Unpublished master's thesis). Stavropol State University, Stavropol, Russia.

\section{Copyrights}

Copyright for this article is retained by the author(s), with first publication rights granted to the journal.

This is an open-access article distributed under the terms and conditions of the Creative Commons Attribution license (http://creativecommons.org/licenses/by/3.0/). 